\title{
Application of Blended Learning (Discovery Learning, Small Group Discussion, Case Study, Role Play \& Simulation, Cooperative Learning, and Collaborative Learning) to Improve Learning Activities and Achivements in Lobby and Negotiation Course
}

\author{
Yesi Puspita*1 \\ ${ }^{1}$ Communication Department, Faculty of Politic and Social,Universitas of Andalas, Padang 25163 Indonesia \\ *Corresponding author. Email: yesifisip@gmail.com, yesipuspita@soc.unand.ac.id
}

\begin{abstract}
The excellent education need evaluation, changes, curriculum development, facilities and infrastructure, good educational management that includes innovative and creative of method and learning model. The practice of Blended Learning on Lobby and Negotiation studies on third year is necessary to improve hard skill and soft skill. The desire output from this learning is the improvement of student's skill in lobby and negotiation for the 2018 class student. Students need to be knowledgeable, good communicator and having a great strategy for winning the war. Students are expected to apply negotiation technique and presentation, activity simulation, able to create portfolio, present their thoughts, confident, independent, disciplined and able to work together as a team by using the knowledge of soft skill. The blended learning method in this course is combined SCL methods, such as discovery learning, small group discussion, case study, role play \& simulation, corporative learning and collaborative learning. This Lobby and negotiation class is conducted for 54 students, with the final result shown the improvement of class activity and class accomplishment with final score grading $\mathrm{A}$ as $90,7 \%, \mathrm{~B}+$ as $7,4 \%$ and $1,9 \%$ failed the class.
\end{abstract}

Keywords: blended, learning, achievement, lobby and negotiation

\section{INTRODUCTION}

The implementation of several learning model by pedagogue is an attempt to deliver knowledge and coordinate and create surroundings system for students to help them having an effective and efficient learning activity with the maximum result. The practice of this Student Centre Model (SCM) can be used for Lobby and negotiation class. Lobby and negotiation is one of the required class for every concentration in Communication Departments. The good ability of lobby and negotiation is needed for gain mutual understanding when difference found in order to achieve specific goal. The lobby and negotiation course is important to show that the use of lobby and negotiations when there are difficulties in life, particularly when critical situation approached students.

This 3 SKS Lobby and Negotiation course requires students to be able to practice the good lobby and negotiation both soft skill and hard skill in their daily lives. This course is quite difficult for students since it's hard to maximize the skill without real practice. The expected output from this course are the student understand the basic knowledge of practical presentation and negotiation, the ability of lobbying prior the negotiation or even during and post negotiation or whether it can be done on the lobby stage only. In this case, students are required to be knowledgeable, the ability to have effective communication and the strategy for winning the war. Students are able to apply the basic knowledge in the form of activity simulation. From the soft skill aspects, students are expected to apply negotiation techniques and presentation, activity simulation, able to create portfolio, present their thoughts, confident, independent, disciplined and able to work together as a team. There are difficulties after 3 years of learning this course found by student class 15 , 16 and class of 17 , it getting worse by today's pandemic 
Covid-19 situation, such as: 1) It's hard for students to stay focus on the learning process with their intimate in touch with smart phone, 2) This is the first time for this course to be hold both online and offline, at this time lecturer are trying to find the best RPS, 3) Lecturer designed a relevant learning scheme to be adopted for this course with the change of learning method from offline to online due to this pandemic Covid-19, 4) Lecturer used the appropriate learning technique to fulfil students soft skill both offline and online, 5) Lecturer created the suitable formula in scoring the students, 6) The course is explained theoretically dominant in the online class because of this pandemic make it hard to have the real practice. Based on the mentioned description above, the Lobby and Negotiation course considered as the important course in Communication Department curriculum and in the implementation of this course, it is necessary to develop the appropriate study method, learning technology to support the learning process, as well as the suitable scoring formula to achieve the expected purpose. In order to get the output of Lobby and Negotiation course, Blended Learning Method is critically needed. The blended learning method in this course is combined SCL methods, such as discovery learning, small group discussion, case study, role play \& simulation, corporative learning and collaborative learning. Balim (2009) "Discovery learning is a method that encourages students to arrive at a con-clusion based upon their own activities and observa-tions". Small group discussion without good classroom organization may be totally ineffective. The arrangement of furniture in the classroom is probably the single most important factor in determining the success of the tutorial. Based on Yin (1981) opinion, case studies are investigations empiricists who investigate phenomena contemporary in the context of life real. Kilgour (2015) The use of roleplays also has the potential to facilitate a more comprehensive learning experience for teacher education students compared to the more traditional cognitive focused approach. Through the role playing method, students can actively develop speaking skills and are skilled in interpreting the material students are learning (Ningsih, 2014:9). Triyanto (2016) Lesson study is a quality teacher development programs through collaborative work between teachers and stakeholders. In lesson study, teachers communicate and cooperate with each other to solve problems in the classroom. Based on Maridi opinion, Collaborative learning is assumed to be a different epistemological perspective sourced from societal constructivism. So that, after the learning process of Lobby and Negotiation course ended, $90 \%$ of students able to be graded as A or A-, and only $10 \%$ graded as B+.

\section{METHODOLOGY}

The method in this research is classroom action research (CAR). Classroom Action Research (CAR) is the research by researcher where researcher's teacher with the point of improvements of learning process and practice (Aqib \& Chotibuddin, 2018:1). Classroom action research is also one of lecturer's effort to improve the quality, roles and responsibility in managing learning process (Sanjaya, 2016:11). Sukardi is also giving opinion about CAR which is the way a group or person organizes conditions so that they can learn about their experiences and make their experiences accessible to others. Classroom action research have several variant of learning with the context of class and room that used in the learning process by lecturer in attempt to solve the problem by lecturer, improve student's hard skill and soft skill with continuity of innovation for a better student's quality and learning achievements. This method using qualitative method to describe data.

Data collection techniques through participative observation, where researcher is actively part of the research in the class action. The observation activity take place in every learning process in online or offline meeting. The other techniques is interview through a discussion with students in class or outside the class. The next techniques is documentation as adding reference book, picture and Lobby and Negotiation course class's video. This research is also using questionnaire. Questionnaire are given twice, before and after the midterm exam. The first questionnaire were about how learning method and learning expectation. The second questionnaire were about final exam question. This research is collaborative research with blended learning method. Researcher is also a part of teaching's team that planned, identified, observed and executed it. The research plan used is classroom action research with spiral system and the Hopkins model.

This research was conducted with Hopkins model which begins with introduction, planning, action, observation and reflection. The research was conducted with two cycles. The result of the first cycles is yet to be done, so improvements were made in the second cycles. The first cycle reflection was conducted to determine the steps for second cycles. Researcher begins with preparing RPS, where there are material plans for one semester and learning method. References and assignment design were also shown in RPS, followed by learning activity in online or offline class. There are plus and min in every learning method. The first cycle is done in the midterm exam, then followed by the second cycles, due to the changes of the learning techniques where face to face kind of learning process turn into online class because of this world pandemic Covid-19, which Padang happen to be one of the worst city in red zone. The cycles continues to be hold in online class until final exam. The discrepancies that occurs so that it is continued to the second cycles is regarding the simulation of Lobbying and Negotiation exercise which is usually carried out by direct practice is hampered. So 
in the second cycles found a formula to fulfil student's soft skill by using media social practice with video of lobbying and negotiation simulation to the society using \#newnormal. Students created persuasive message to how living the life in the new normal with government statement "The manner of new normal lifestyle". This research is done in the fourth semester in the year of 2020. This research activity is estimated to finish in one semester of learning in the year of 2019/2020. This research is divided by two cycles, the first cycles is begin from course contract until midterm exam from January $22^{\text {nd }} 2020-$ March $9^{\text {th }} 2020$, the second cycles begins at March $23^{\text {rd }} 2020$ - May 2020 (the online class has been started due to the pandemic Covid-19). The subject of this research are 54 students majoring communications science.

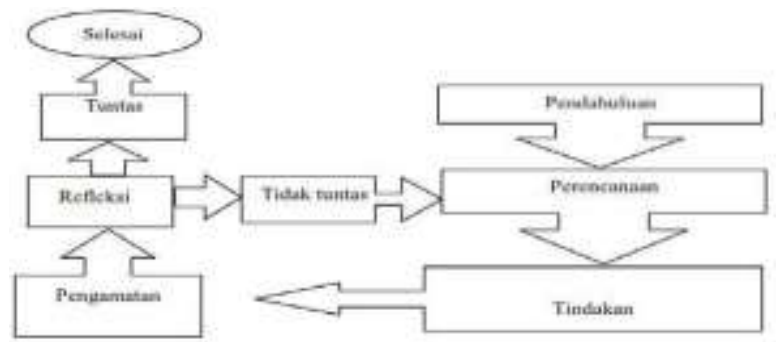

Image 1. The design of CAR based on the Hopkin Model Adaptation

This research was conducted with Hopkins model which begins with introduction, planning, action, observation and reflection. The research was conducted with two cycles. The result of the first cycles is yet to be done, so improvements were made in the second cycles. The first cycle reflection was conducted to determine the steps for second cycles. The research stages that carried out are as followed: first cycles: 1) Planning stages: compile a learning plan with presentation method as a corrective action, prepare learning media such as case study and contemporary issues about lobby and negotiation, prepare learning method through online and offline media, compile observation guideline, compile student's evaluation tools. 2) Action stage: first activity, lecturer prepared learning media and engaged students to convey their presentation about a good lobbying and negotiation, then generate passion of learning among students by question and answer session and evaluate their presentation. The lecturer's main activity in this stage was: lecturer explained lobby and negotiation learning materials, lecturer convey learning materials then the students presented it, lecturers facilitated learning process using SCL method, lecturer determine class's project during the semester, lecturer engaged students to identified which situation is best to practice lobby and negotiation, lecturer together with students discussed case study of lobby and negotiation, lecturer gave an opportunity to students to have each other questions answered, respond and perform creative and innovative lobby and negotiation, lectures gave evaluation sheets to students, final activity, at the end of the class lecturer summed up the result and explained the advantages of learning by student learning centre method with the practice of blended learning (discovery learning, small group discussion, case study, role play \& simulation, cooperative learning, and collaborative learning) to improve student's activity and accomplishment in this lobby and negotiation course. 3) Observation stage, involving several parties such as lecturer's team, researcher and colleagues. This stage is performed during learning process using the guidelines of observation sheets that already created by researcher. The thing need to be observe by researcher are student activities during learning process to make sure the plan is well executed. Then, conducted result observation analysis to find out liveliness of students, lecturer and the course of learning. 4) Reflection stage, all the results of observation, student's evaluation and record of real practice are analyzed, explained and concluded in this stage. The purpose of this stage is to know the successfulness of learning process based on project using media technology. Researcher together with observer analyzed result of first and second cycles to consider the next cycles. Second cycles is the corrective action from the first cycles that has not been successful. Generally, the implementation of second cycles is the same as the first cycles, it is just the second cycles is more thorough noticing what is yet to be achieved in the first cycles. This is done to achieve the expected goals. The output of this research are: new RPS, article about the result of SLC from the development of learning method, curriculum, learning technology and student's assessment, the strategy of this attainment will be described as: learning plan on the previous RPS is not really comprehensive regarding components of learning attainment from the behavioral changes, knowledge improvements and ability to master the skill. All the components need to be summarized clear and detail on RPS that has been perfected. In addition, a learning plan will be formulated that contains: 1) Learning process activity conducted by lecturer to be the learning experience for students, 2) Systematics learning steps to achieve the objective of learning, 3) Detailed steps of learning process to help other lecturers understand the RPS easily without bias. This is intended to be the guidelines for lecturers and students in future learning process. The approach of this classroom action research is using SLC's approach with discovery learning method, small group discussion, case study, role play and simulation, corporative learning and collaborative learning. The method that developed in this Classroom action research is student learning method (SLC) that one of learning method which centralized student's learning activity and lecturer's teaching activity with result implementation as: 1) Student's assignment: correctly choose the lobby and negotiation to be presented, devise lobby and negotiation practice, hold 
practice and preparations, use all resources to practice lobby and negotiation, reporting progress periodically and scheduled to lecturer. 2) Lecturer assignment: Convey learning objective, convey criteria or standards and expectation to students with the finalize of practice, explain learning plans and procedures, divide students into groups with 3 to 4 persons per group, the establishment of group's member is to trained the students having well presentation practice, give learning contract to students, provide students the helps needed, observe progress lobby and negotiation practice, give formative or summative score. Student assessment's development is measured thorough learning accomplishment. Student ability is shown by their ability to master the knowledge, attitude, skills that they gained during learning process. Learning accomplishment is used as the student's description of successfulness to understand the particular studies. Every effort put in learning activity is for achieve the highest learning accomplishment (hard skill and soft skill). This learning accomplishment is stated with score. The student assessment's development in this research are as follows: participation, performance observation, written test, oral test, questionnaires. Student scoring is done by: 1) Process scoring: paper, presentation and practice. 2) Result scoring: portfolios that explain how lecturer able to scored students. Performance parameters in curriculum action research covers: result achievement: cognitive and affective habitual changes, mastery of concept lobby and negotiation improvements, mastery of substantial improvements, mastery of particular skill in lobby and negotiation improvements, complete practice lobby and negotiation, habitual changes (psychomotor and affective). The Final result of 54 students in this Lobby and Negotiation course, 49 students were given grades $\mathrm{A}$ and $\mathrm{A}-,, 4$ students were given grades $\mathrm{B}+$ and 1 students were BL due to class cancelation.

\section{RESULTS AND DISCUSSION}

Based on the application of blended learning in lobby and negotiation course for students of 2018 get a very satisfying result because of the percentage of the score $90,7 \%$ get an A, it can be seen from the following dfigure:

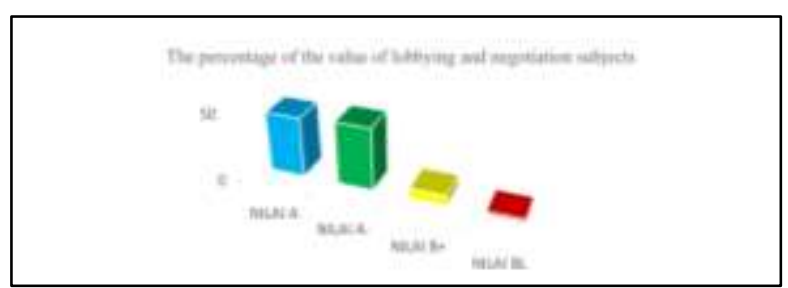

Image 2. Percentage of student scores in lobbying and negotiation courses Class A class 2018

The practice of discovery learning prior pandemic were held in the class by material presentation, to be able to give well presentation, student need to understand the material independently to make in line with audiences. During the pandemic, the class were still held as normal by using room chat in online class, material presentation were still given thorough text or video.

The practice of small group discussion were to solving the problem related to material by divided class into 13 groups. The preparation for a discussion class needs to marry process and content - we are looking for ways to communicate, to enliven, and to bring home the content, we want to find ways to help learners to internalize the theory (Kelly, 1993). This kind of activity is to discuss every learning material in every meeting. There are 3 to 4 persons in each group with assignment as follows: looking for material (find by more than one person), compile material (compiled by one person), create power point (created by one person), the presentation id responsible of every member of the group, question and answer session (all group member work in team to find the answer of questions given), sharpening and closing statement from lecturer. When the pandemic attacked, small group discussion method were still running, since there room chat provided to every group discussed their material. The constraint of this method is time, which takes longer because the discussion move from discussion room to class room chat.
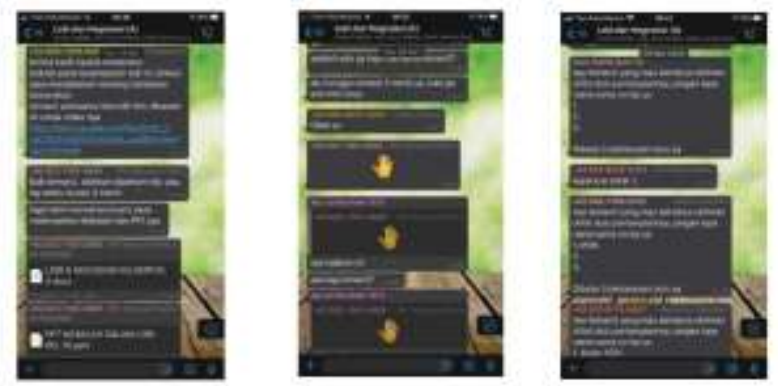

Image 3. Room chat activity discovery learning and small group discussion

The application of the case study was made in the form of a video where the message was able to lobby and negotiate the community to be aware and survived in new normal life. a case study is an inquiry empiricists who investigate phenomena in in real life contexts, limits between the phenomenon and the invisible context clear, and multiple sources of evidence were utilized (Yin, 1981). The cases are: 1) how to prevent the spread of covid-19, 2) how to wash hands properly, 3) masks for all, 4) how to use and wash the correct cloth masks, 4) tips on preventing Covid-19 on public transportation, 5) tips for preventing covid-19 at work, 6) tips for preventing covid-19 after traveling, 7) Tips for maintaining endurance, 8) tips on food safety at food stalls, 9) food safety tips in restaurants, 10) safety tips selling cakes traditional, 11) food safety tips by creative 
field traders, 12) safety tips at retail facilities, 13) online food shopping tips. This video is displayed on social media such as YouTube and Instagram so that it is known by the public.

The Role Play and Simulations are more interested and attractive to applied in online class. Learners become conscious of their strengths and weakness as they reflect upon themselves how well they had performed the role. The role play and simulation for this lobby and negotiation online class called "Andalas Airlines seri lobi negosiasi", where each of the student will have part to do the simulation. This is where the lecturer will role as the pilot, and the class leader will be the co-pilot that in charge to all student during the flight. Then the presentation team will be the cabin crew that in charge of providing explanations during the flight. Of course the subject matter will be made as interesting as possible such as when the flight attendance and stewardess give aircraft safety instructions and will added a little bit of with some poem to make the online class more interesting.
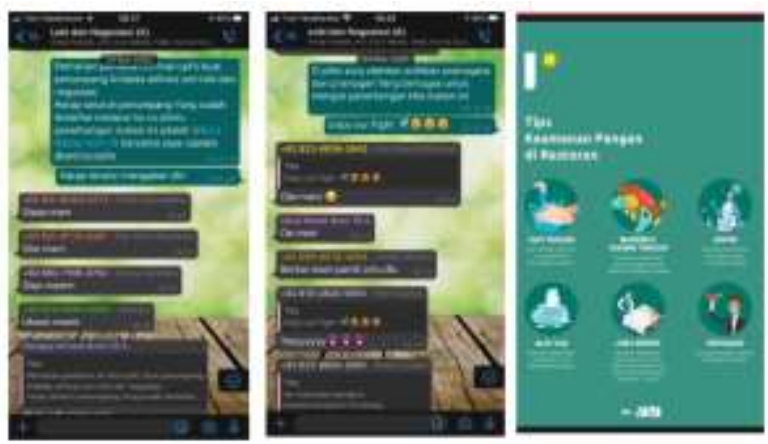

Image 4. Room chat activity role play and simulation

The use of cooperative learning role play and simulation will be directed by the lecturer by giving group assignments to make material presentation, giving the students a time to do their presentation and instruction to make video about lecture materials and virtual lobby and negotiation parquet, as well as reviewing presentations, materials and adding explanations.

The application of collaborative learning Role Play and Simulations are more interested and attractive to applied in online class. Bruffee (1984) Organizing collaborative learning effectively requires doing more than throwing students together with their peers with little or no guidance or preparation. The role play and simulation for this lobby and negotiation online class called "Andalas Airlines seri lobi negosiasi", where each of the student will have part to do the simulation. This is where the lecturer will role as the pilot, and the class leader will be the co-pilot that in charge to all student during the flight. Then the presentation team will be the cabin crew that in charge of providing explanations during the flight. Of course the subject matter will be made as interesting as possible such as when the flight attendance and stewardess give aircraft safety instructions and will added a little bit of with some poem to make the online class more interesting.
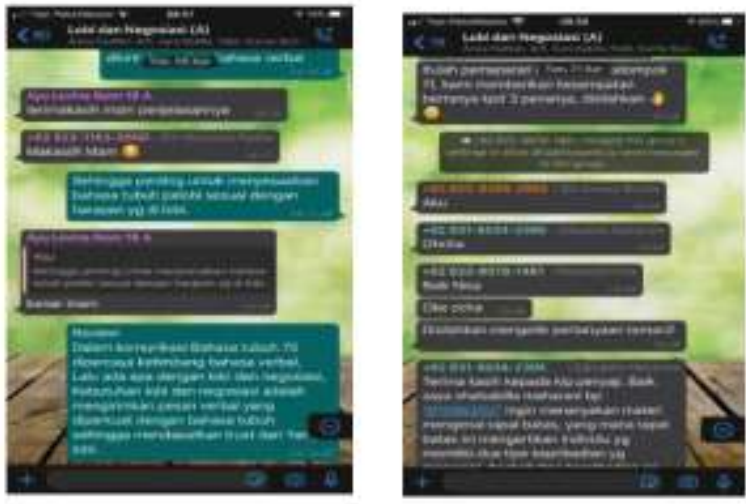

Image 5. Room chat activity role play and simulation

\section{CONCLUSION}

From the application of the blended learning method in the Lobbying and negotiation subject in the 2019/2020 academic year, it can be concluded that the implementation of blended learning with the discovery learning, small group discussion, case study, role play \& simulation, cooperative learning, and collaborative learning methods has a positive effect on the development of student abilities. Both hard skills and soft skills. This conclusion can be seen from the significant increase in learning outcomes during the Middle Test (UTS) until the Final Exams (UAS) which most of student from 54 but 49 of a precentage of 90,7 get an A.

\section{ACKNOWLEDGMENT}

This work was supported by Institute of Educational Development and Quality Assurance (LP3M) Universitas Andalas under SK Rektor Universitas Andalas No. 100/XIII/R/KPT/2020

\section{REFERENCES}

[1] Abidin, Mohamad Jafre Zainol., Osman, Siti Rafizah Fatimah., dan Hosseini, Moniro Sadat. 2012. "Role-Play: Taking the Line of Least Resistance". International Journal of Learning \& Development ISSN 2164-4063 2012, Vol. 2, No. 2.

[2] Aqib, Zainal \& M. Chotibuddin. 2018. Teori dan Aplikasi Penelitian Tindakan Kelas: (PTK). Yogyakarta: Deepublish

[3] Basuki, Ismet dan Hariyanto. 2014. Asesmen Pembelajaran. Bandung: PT. Remaja Rosdakarya Offset.

[4] Balim, A. G. 2009. "The Effect of Discovery Learning on Students Success an Inquiry Skills". 
Eurasian Journal of Educational Research/ Issue 35, 1- 21.

[5] Bruffee, K. A. (1984). Collaborative Learning and the "Conversation of Mankind". College English, 635-652.

[6] Hanafiah, Nanang. (2010). Konsep Strategi Pembelajaran. Bandung: PT Reflika Aditama.

[7] Kilgour, Peter., Reynaud, Daniel., Northcote, Maria., dan Shields, Marion. 2015. "Role Playing As A Tool To Facilitate Learning, Self Reflection And Social Awareness In Teacher Education". International Journal of Innovative Interdisciplinary Research

[8] Lie, Anita. 2002. Cooperative Learning: Mempraktikkan Cooperative Learning di Ruangruang Kelas. Jakarta: Grasindo

[9] Maridi. 2009. Penerapan Model Collaborative Learning. Surakarta (online) (https://media.neliti.com/media/publications/17543 6-ID-penerapan-model-collaborative-learning.pdf)

[10] Ningsih, Dita Tricandraria, dkk. 2014. "Metode Role Playing untuk Meningkatkan Aktivitas dan Hasil Belajar". Jurnal. Fakultas Keguruan dan Ilmu Pendidikan Universitas Lampung Bandar Lampung.

[11] Sanjaya. Wina 2009. Penelitian Tindakan Kelas. Jakarta: Kencana.

[12] Sukardi. (2013). Metode Penelitian Tindakan Kelas. Jakarta: Bumi Aksara.

[13] Suprijono, A. (2009). Cooperative Learning Teori dan Aplikasi PAIKEM. Yogyakarta: Pustaka Pelajar.

[14] Sulisworo, D., \& Suryani, F. 2014. The Effect of Cooperative Learning, Motivation and Information Technology Literacy to Achievement. International Journal of Learning \& Development, (Online), 4(2), (http://macrothink.org/journal/index.php/ijld/article /view/4908/4439)

[15] Slavin, R. E. 2005. Cooperative Learning Teori, Riset, dan Praktik. Terjemahan oleh Nurulita Yusron. Bandung: Nusa Media.

[16] Triyanto. 2016. Building Collaborative Learning Through Lesson Study. (online) (https://media.neliti.com/media/publications/16938 8-EN-building-collaborative-learning-through.pdf)

[17] Kagan, S. \& Kagan, M. (2009). Kagan Cooperative Learning. San Clemente: Kagan Publishing.

[18] Kelly, M., Stafford, K. (1993). Managing Small
Group Discussion. Workshop Series No.9. (1993). 1-18.

[19] Wijayati, I. W. 2016. The Effectiveness of Two Stay Two Stray Technique in Teaching Reading Through Procedure Text for Eleventh Grade Students Of SMK Maospati In The Schooling Year Of 2015/2016. Jurnal Ilmiah Pendidikan, (Online), (stkipdrnugroho.ac.id/up-pdf5/jurnal/4-ida.pdf),

[20] Yin, Robert. (2009). Studi Kasus (Desain \& Metode). Jakarta: Rajawali Pers.

[21] Arikunto, S., Suhardjono, \& Supardi. 2015. Penelitian Tindakan Kelas. Jakarta: PT Bumi Aksara. 